\author{
Kh. I. Kabel*, Ah. A. Farag, E. M. Elnaggar, A. G. Al-Gamala \\ (Cairo, Egypt) \\ *drkhalid1977@yahoo.com
}

\title{
Improvement of graphene oxide characteristics depending on base washing
}

Graphene oxide (GO) has been synthesized using Hummer's method. This oxidation process decorates the graphene sheets by different types of functional groups, yet the harsh oxidation condition leads to introduce many of carbonaceous fragments, which decreasing GO efficiency in many faces, touched its applications. The synthesized GO has been washed by $10 \mathrm{M} \mathrm{NaOH}$ to produce $\left(G O_{n}\right)$. Thereafter quality enhancement of $G O$ has been studied by several analyses; the introduced hydroxyl and carboxyl groups into few-layer graphene (FLG) surface have been determined by Fourier transform infrared spectra (FTIR). Raman spectroscopy analysis identified the defect degree and the transition of graphite from a crystalline to an amorphous structure and vice versa. The interlayer spacings of FLG and $G O_{n}$ were investigated by $X$ ray diffraction (XRD) and the thermal stability of as-received and modified materials were examined by thermal gravimetric analysis (TGA). The morphological structure was characterized by scanning electron microscopy (SEM) and high resolution transmission electron microscopy (HRTEM). The various investigations confirmed that the properties of $G O$ were improved by neutralization impact, which may pave the way to new developments in the GO-based applications.

Keywords: oxidation, graphene oxide, few-layer graphene, carbonaceous fragments, electrostatic stabilization.

\section{INTRODUCTION}

Graphene, one of the allotropes of elemental carbon (carbon, carbon nanotube, fullerene, diamond) $[1,2]$, is a planer monolayer carbon atoms arranged in two-dimensional (2D) honeycomb lattice with a Carbon-Carbon bond length of $0.142 \mathrm{~nm}$ [3]. It can be divided into three different types: single-layer graphene (SLG), bi-layers graphene (BLG) and few-layer graphene (FLG) [4]. Graphene has received a worldwide attention due to its exceptional charge transport, thermal, optical and mechanical properties; it can be synthesized by several methods as micromechanical cleavage, chemical vapor deposition (CVD), and reduction of graphite oxide to graphene. The functionalization of graphene improves its dispersibility and enhances its functions in various applications [5]. Graphene oxide (GO) can be obtained by liquid phase oxidation of graphene sheets. Chemically, both graphite oxide and GO have similar or identical structures, both possess stacked structures with chemicals on their basal planes and at their edges [1]. The only difference between them is the number of stacked layers; GO possess a monolayer or just a few stacked layers $(\leq 10)$, while graphite oxide $(>10)[1,6]$.

In general, the liquid phase oxidation of graphene was developed several decades ago by Brodie [7], Staudenmaier [9] and Hummers et al. [10]. The Hummers method is generally more used in current research, it has shorter reaction time and absence of highly toxic gas $\mathrm{ClO}_{2}$ [11]. The disadvantage of the Hummers method 
is the contamination by excess permanganate ions, which should be removed by treatment with $\mathrm{H}_{2} \mathrm{O}_{2}$ [12], followed by washing several times through a membrane.

The Hummers method uses a combination of potassium permanganate and sulfuric acid to obtain (manganese heptoxide) as (according to equations) below.

$$
\begin{gathered}
\mathrm{KMnO}_{4}+3 \mathrm{H}_{2} \mathrm{SO}_{4} \rightarrow \mathrm{K}^{+}+\mathrm{MnO}_{3}^{+}+\mathrm{H}_{3} \mathrm{O}^{+}+3 \mathrm{HSO}_{4}^{-} ; \\
\mathrm{MnO}_{3}^{+}+\mathrm{MnO}_{4}^{-} \rightarrow \mathrm{Mn}_{2} \mathrm{O}_{7} .
\end{gathered}
$$

GO is heavily oxygenated, highly hydrophilic, and readily exfoliated in water producing stable dispersion consisting mostly of a single layer of GO [5]. The distribution of oxygen-containing functional groups on graphene oxide structures have been studied using ${ }^{13} \mathrm{C}$ NMR $[13,14]$. Lerf-Klinowski suggested that, when oxygen located in the carbon basal plane as hydroxyl and epoxy groups compose $\mathrm{sp}^{3}$ hybridization. In addition, when oxygen located at the sheet edges as carbonyl and carboxyl it enhances $\mathrm{sp}^{2}$ hybridization $[7,15,16]$. The ratio of $\mathrm{sp}^{2} / \mathrm{sp}^{3}$ in GO may provide novel properties that can be useful in various applications such as chemical sensors and biosensors, super capacitors, energy storage, nanocomposites, electronic and optoelectronic devices, and so on $[5,17]$. The oxidation process can cut the graphitic layers into smaller fragments called 'oxidation fragments' [18]. These fragments are not removed from the sample in conventional treatments; however, they can be successfully removed by an aqueous base washing [19].

In this article, we oxidized FLG powders to GO using modified Hummer's method as well as removing the oxidized fragments and contaminating metal by highly concentrated base washing to produce $\mathrm{GO}_{n}$. The morphological structure of GO was studied using scanning electron microscopy (SEM) and high-resolution transmission electron microscopy (HRTEM). The order of crystallinity was measured by X-ray diffraction (XRD). The defects on the surface of GO were detected by Raman spectroscopy. The thermal stability was determined by thermal gravimetric analysis (TGA). The efficient of the oxidation process was observed by Fourier transform infrared spectra (FTIR).

\section{EXPERIMENTAL}

\section{Materials}

Rods of graphene, provided by VEB Elektrokohle Lichtenberg, REKIPRO (Germany), were crushed in 20-25 $\mu \mathrm{m}$ using Retsch ball mill PM400 (Germany), sulfuric acid (98\%), hydrochloric acid (37\%) and potassium permanganate were purchased from Sigma-Aldrich Co. (Germany). Hydrogen peroxide (30 \% v/v) and sodium nitrate were purchased from (El Nasr Company for Intermediate Chemicals, Egypt).

\section{Synthesis of graphene oxide and $\mathrm{NaOH}$ wash}

Graphene oxide was synthesized from the natural graphite powders using Hummer's et al. method [10]: $1 \mathrm{~g}$ of FLG, $1 \mathrm{~g}$ of $\mathrm{NaNO}_{3}$ and $46 \mathrm{ml}$ of concentrated $\mathrm{H}_{2} \mathrm{SO}_{4}$ were mixed together in three necked flask equipped with a magnetic stirrer and thermometer in an ice bath for about $30 \mathrm{~min}$ at $0{ }^{\circ} \mathrm{C}$. Then $3 \mathrm{~g}$ of $\mathrm{KMnO}_{4}$ was added to the suspension carefully to prevent the temperature exceed $20^{\circ} \mathrm{C}$. The ice bath was removed and the temperature of the suspension raised to about $35 \pm 3{ }^{\circ} \mathrm{C}$, where it was mentioned under stirring for 30 minutes to become pasty brownish gray in color. The thickened paste was stirred slowly with $46 \mathrm{ml}$ of de-ionized water and the temperature increased to $98{ }^{\circ} \mathrm{C}$, the color of the suspension changed to brown, it was kept stirring for 30 minutes. Finally, it was further diluted with 
approximately $140 \mathrm{ml}$ of warm water and treated with $10 \mathrm{ml}$ of $\mathrm{H}_{2} \mathrm{O}_{2}$. The acidic suspension was neutralized by $82 \mathrm{ml}$ of $10 \mathrm{M} \mathrm{NaOH}$. The suspension was filtered, resulting yellowish-brown filter cake which washed with de-ionized water for several times. Then the filter cake was treated with $3 \% \mathrm{HCl}(1 \mathrm{M})$ solution to regenerate the functional groups [20], it was dispersed and washed with deionized water for several times. The resulting sample was dried by lyophilization using (vacuum desiccator) to avoid the aggregation of graphene oxide during the drying process $[21,22]$.

\section{Instruments}

X-ray diffraction (XRD) analysis was performed on an X-ray diffractometer from PANlytical company model (X'Pert Pro) $2 \Theta$ range from $5^{\circ}-90^{\circ}$ conditions $40 \mathrm{~mA}, 40 \mathrm{kV}$, and wave length of Copper $K \alpha_{1}$ at $1.54 \AA$. The (FTIR) Fourier transform infrared spectrum $\left(400-4000 \mathrm{~cm}^{-1}\right)$ was measured the addition of carboxyl and hydroxyl groups on the graphene surface using (Thermo Fisher Scientific; Nicolet iS10 FTIR spectrometer, USA), the sample was mixed with pure KBr as the background, then the mixture was dried and compacted into a transparent tablet for measurement. The Raman analysis was investigated by laser as an excitation source at wavelength $532 \mathrm{~nm}$, using dispersive Raman spectrosmeter (Senterra, Bruker, Germany), the laser spot size was $1 \mu \mathrm{m}$ and the temperature of the sample was maintained at room temperature. The thermal stability was assessed by the thermal gravimetric analysis (TGA) (SDT Q600 V20.5 Build 15) in the temperature range of $20-850{ }^{\circ} \mathrm{C}\left(10{ }^{\circ} \mathrm{C} / \mathrm{min}\right)$ under a nitrogen atmosphere. The shape and the surface morphology of the samples was analyzed using high resolution transmission electron microscope (HRTEM), of JEOL JEM-2100F, Japan at $200 \mathrm{kV}$. The samples were sonicated to dispersing the aggregation of the graphene sheet, carried out on ultrasonic bath (Sonic Star, $50 \mathrm{kHz}, 300 \mathrm{~W}$ ). A Waterproof CyberScan Series $310 \mathrm{pH}$ meter was used for measuring $\mathrm{pH}$ during the experiment.

\section{RESULTS AND DISCUSSION}

\section{FTIR characterization}

FTIR spectra of FLG and $\mathrm{GO}_{\mathrm{n}}$ samples are shown in Fig. 1. In Fig. 1 (curve 1), the appearance of two strong peaks at $1601 \mathrm{~cm}^{-1}$ referred to conjugation system $(\mathrm{C}=\mathrm{C}-\mathrm{C})$ stretching [23]. In Fig. 1 (curve 2), the peak at $1054 \mathrm{~cm}^{-1}$ referred to aliphatic stretching of $(\mathrm{C}-\mathrm{O})$, the peak at $1161 \mathrm{~cm}^{-1}$ referred to stretching ether system $(\mathrm{C}-\mathrm{O}-\mathrm{C})$, the peak at $1601 \mathrm{~cm}^{-1}$ referred to stretching conjugation system $(\mathrm{C}=\mathrm{C}-\mathrm{C})$, the peak at $1725 \mathrm{~cm}^{-1}$ referred to carbonyl group $(\mathrm{C}=\mathrm{O})$, the peak at $2918 \mathrm{~cm}^{-1}$ referred to bending and stretching of methylene group $\left(-\mathrm{CH}_{2}-\right)$ and broad band at $3340 \mathrm{~cm}^{-1}$ are attributed to vibration of a hydroxyl group $(\mathrm{O}-\mathrm{H})[2$, 24]. The FTIR observed that the oxidation process was successfully occurred, a new groups as hydroxyl, carboxyl and epoxy have been introduced into the graphene layers.

\section{XRD analysis}

The XRD analysis was used to characterize the crystallinity and purity of the oxidized FLG (GO) after high concentration base washing. The XRD patterns of the pristine FLG and $\mathrm{GO}_{\mathrm{n}}$ are shown in Fig. 2. Their interlayer spacing $(d), 2 \theta$ diffraction and the relative intensity have been illustrated in Table 1. The XRD pattern of graphitic substrate shows peak at $2 \theta=26.53^{\circ}(002)$ corresponding to an interlayer spacing $(d)=3.33 \AA$. The FLG appeared broad peaks at $2 \theta=25.53^{\circ}$ $(002)$ and $45.89^{\circ}(100)$ which are attributed to graphene sheet material correspond- 
ing, $(d)=3.48 \AA$ and $1.83 \AA$ respectively $[2,25]$. After oxidation using $3 \mathrm{~g} \mathrm{KMnO}_{4}$ results in the following changes, the peak of graphene sheets becomes narrow and shifted in the lower diffraction angle at $2 \theta=22.56^{\circ}$ corresponding to $(d)=3.94 \AA$, meaning that the interlayer distance increases and the structure was modified. The XRD pattern shows the feature peak at a lower diffraction angle $2 \theta=10.85^{\circ}$ corresponding to $(d)=8.15 \AA$, confirmed oxidation of FLG to GO. After washing with high concentration $\mathrm{NaOH}$ the XRD pattern shows a new peaks were appeared, attributed to the structural deformation, which occurred by the decomposition of epoxy groups to hydroxyl groups and - $\mathrm{ONa}$ [26].

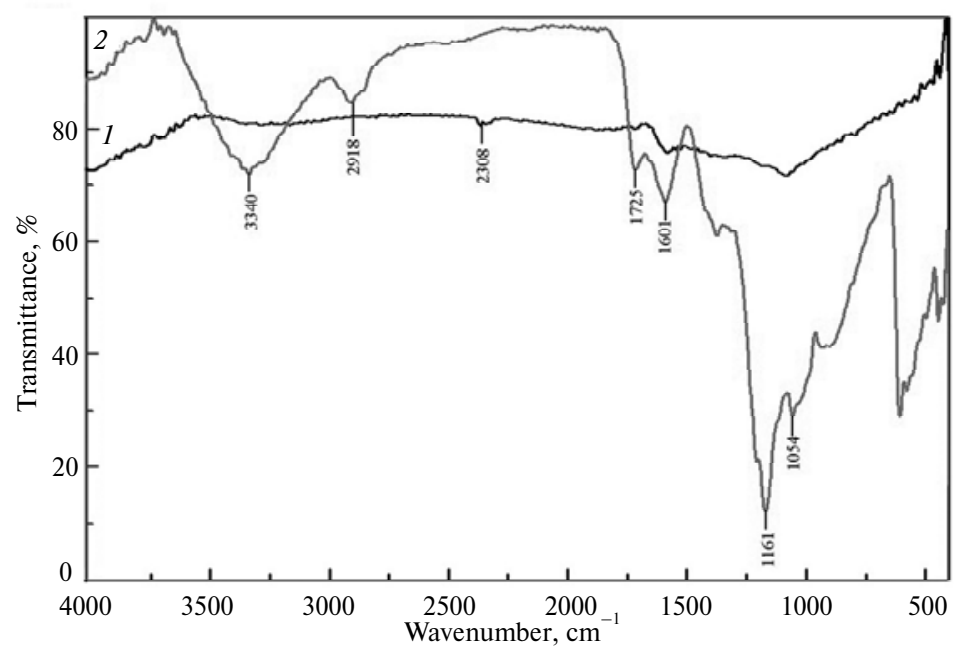

Fig. 1. FTIR spectra of FLG (1) and $\mathrm{GO}_{n}(2)$.

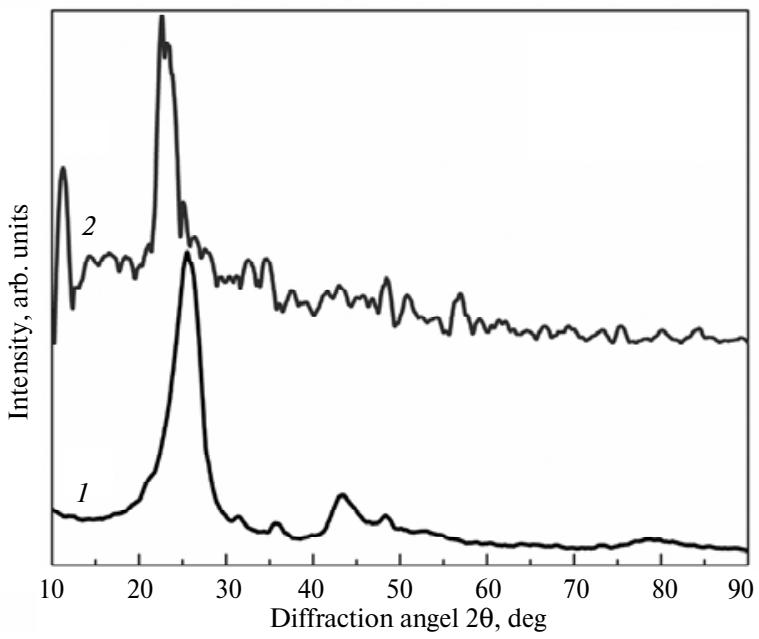

Fig. 2. XRD of FLG (1) and $\mathrm{GO}_{n}(2)$.

\section{Raman analysis}

Raman spectroscopy is a standard nondestructive tool to characterize carbonaceous materials, especially to distinct ordered and disordered crystallinity of the structures of carbon. From Fig. 3 we can show that, the main features of the graphite materials are $G$ band at about $1575 \mathrm{~cm}^{-1}, D$ band at about $1345 \mathrm{~cm}^{-1}$. The $G$ 
band represents a first order scattering of $E_{2 g}$ mode, while the $D$ band is the evidence for the presence of defects in the graphite material [26, 27]. The last important band is the overtone band of the $D$ band ( $2 D$ band) which appears at $2705 \mathrm{~cm}^{-1}$ [28]. The stacking order of the graphite layers along the $c$-axis were assessed by the $2 D$ band, where the intensity of $2 D$ band displays for SLG, BLG and FLG as descending order [29, 30].

Table 1. Interlayer spacing $d, 2 \theta$ diffraction and relative intensity of $\mathbf{G O}_{n}$ and FLG

\begin{tabular}{c|c|c|c}
\hline Sample & $2 \theta$ & $d, \AA$ & Relative intensity, \% \\
\hline \multirow{2}{*}{ FLG } & $26.53^{\circ}$ & 3.33 & 100.00 \\
& $25.53^{\circ}$ & 3.48 & 89.00 \\
& $44.43^{\circ}$ & 1.83 & 6.71 \\
$\mathrm{GO}_{n}$ & $23.62^{\circ}$ & 3.76 & 100.0 \\
& $22.56^{\circ}$ & 3.94 & 75.45 \\
& $45.13^{\circ}$ & 2.00 & 12.54 \\
& $10.85^{\circ}$ & 8.15 & 16.20 \\
\hline
\end{tabular}

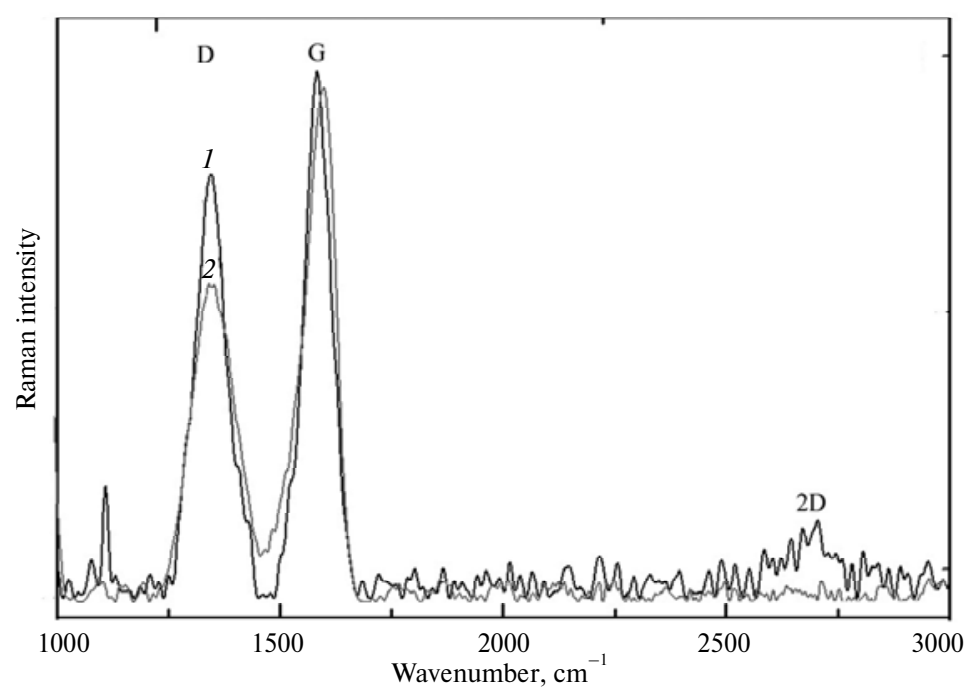

Fig. 3. Raman spectra of FLG (1) and $\mathrm{GO}_{n}$ (2).

The oxidation process has changed the structure of the graphene lattice due to introducing of different functional groups at the basal plane and also at the edges. The $G$ band of $\mathrm{GO}_{n}$ is shifted towards a higher wave number at about $1600 \mathrm{~cm}^{-1}$ related to the formation of $\mathrm{sp}^{3}$ carbon atoms in the graphene lattice [31]. The intensity of $D$ band of $\mathrm{GO}_{n}$ is lower than pristine FLG, due to the high concentration base washing lead to eliminating the amorphous carbon. The relative intensity $I_{(D)} \mathrm{I}_{(G)}$ is very useful to detect efficiency of oxidation and purification processes. We can observe that $I_{(D)} / I_{(G)}$ of FLG and $\mathrm{GO}_{n}$ are 0.82 and 0.62 , respectively, the relative intensity is decreased due to removal of amorphous carbon and other impurities using high concentration $\mathrm{NaOH}$ that leads to diminishing the $D$ band value. A careful inspection of Raman spectra observed that, the overtone $2 D$ band disap- 
peared in $\mathrm{GO}_{n}$ due to the breakage of the stacking order along the $c$-axis during the oxidation process [17].

\section{The morphology and crystallinity analysis}

Figure 4 shows the SEM images of FLG and $\mathrm{GO}_{n}$. It can be seen that the appearance of the surface is more flat and straight due to the layers of graphene were arranged in order due to the strong layer-layer interaction (Van der Waals force) and the sample is looking black [2], as these appear in images (see Figs. 4, $a, b$ ) of the original FLG. On the other hand, from Figs. $4, c, d$ we can show that, the surface and edge of $\mathrm{GO}_{n}$ were rough and wrinkled. This indicates that the regular lamellar structure of FLG has been distributed after the oxidation process; the wrinkle was caused because the distribution of hydrogen bonds is non-uniform, which formed between hydroxy groups. The oxidation process has been transformed the arranged layer structure to a worm-like structure with many apertures by widening and exfoliation along the $c$-axis of a graphite crystal.

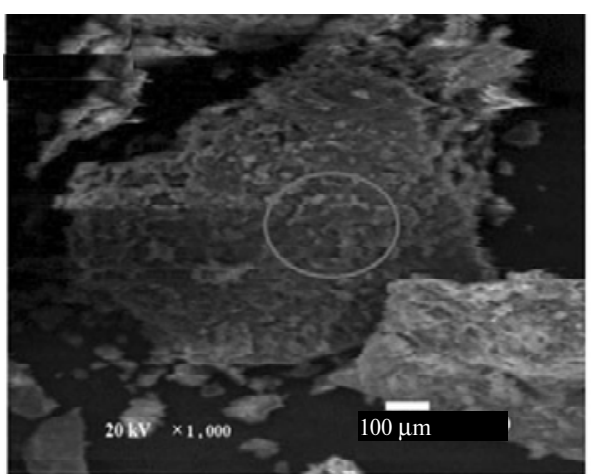

$a$

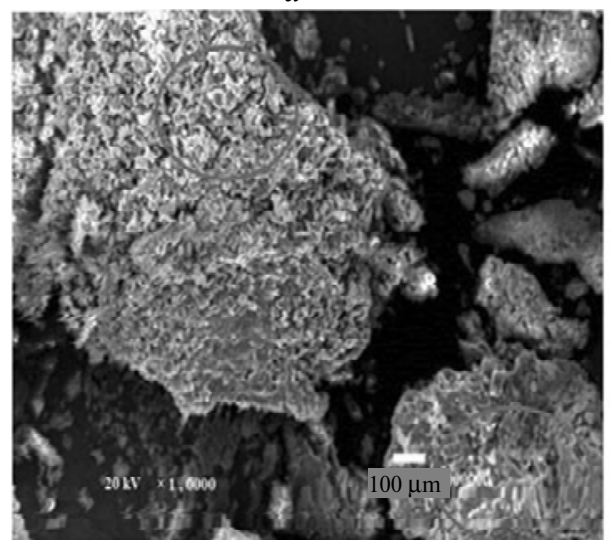

$c$

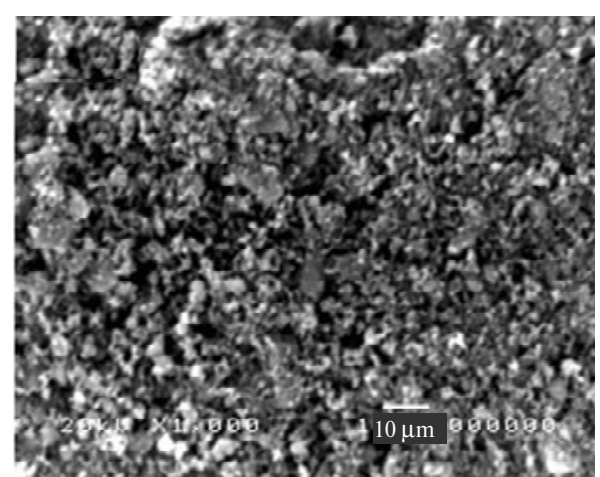

$b$

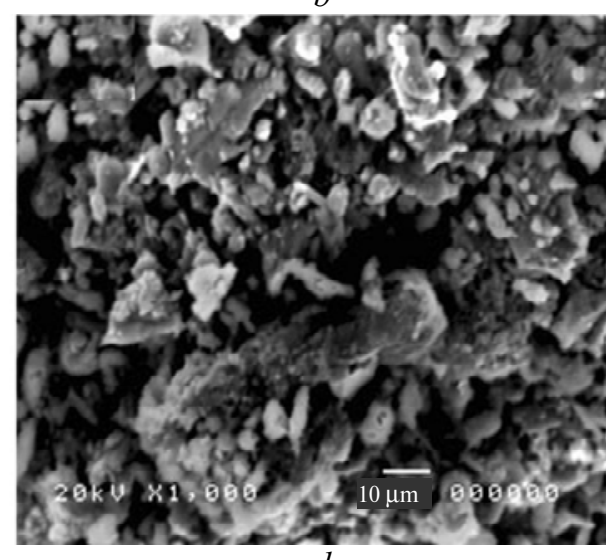

$d$

Fig. 4. SEM analysis of ( $a$ ) graphitic layer-layer interaction for FLG; $(b)$ the magnification of the image $(a) ;(c)$ appearance of wrinkles on the surface of $\mathrm{GO}_{n}$ after base washing; $(d)$ the magnification of the image $(c)$.

The morphological structure and the crystalline kind of FLG and $\mathrm{GO}_{n}$ were characterized by HRTEM. Figure 5 shows that the samples consist of layers with different transparences, it may be attributed to the number of layers existed in the aggregated structure [17]. From Fig. 5, $a$ it can be observed that the bulk morphology of FLG compressed of many graphite layers and it is completely dark. On the contrary, the image of $\mathrm{GO}_{n}$ (see Fig. $5, b$ ) becomes highly transparent due to pos- 
sessing high amounts of oxygenated content after oxidation process, which makes suitable for exfoliation of graphite layers into a monolayer or just a few layers of GO after ultrasonication. Also, after oxidation a reduction in the dimensions of graphitic sheets has been observed.

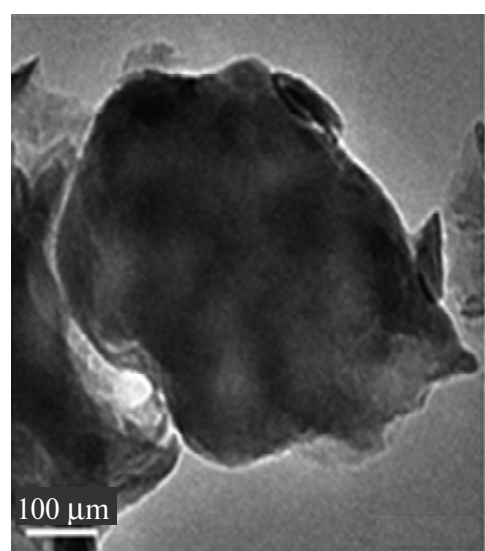

$a$

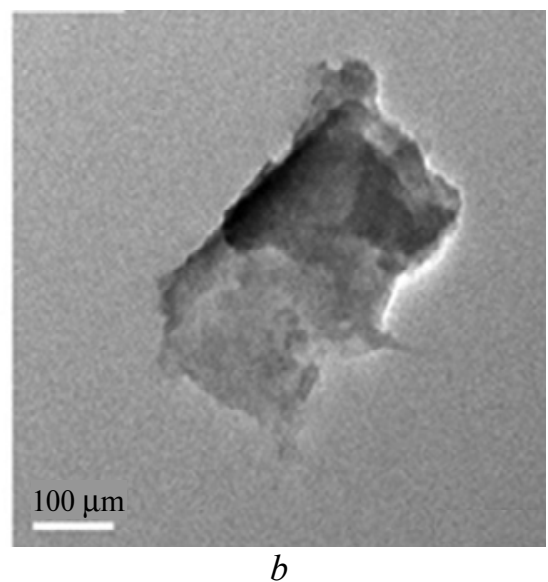

b

Fig. 5. HRTEM of FLG $(a)$ and $\mathrm{GO}_{n}(b)$.

\section{TGA analysis}

The thermal behaviors of pristine FLG, $\mathrm{GO}$ and $\mathrm{GO}_{n}$ were examined by thermal gravimetric analysis (TGA) in dry air, to find the efficient graphitic matter oxidation and possible structural damage. The TGA curves and data are shown in Fig. 6 and Table 2. The pristine FLG has started to lose weight at $46.6^{\circ} \mathrm{C}(7.6 \%)$ related to the physical adsorbed moisture, the sharpness weight loss at $650{ }^{\circ} \mathrm{C}$ due to the combustion of the carbon backbone to carbon dioxide [26]. The GO powder exhibit three steps of weight loss that start at $58.4^{\circ} \mathrm{C}(17 \%)$ related to the physical adsorbed moisture, the second and the last weight loss at $258^{\circ} \mathrm{C}(40 \%)$ and

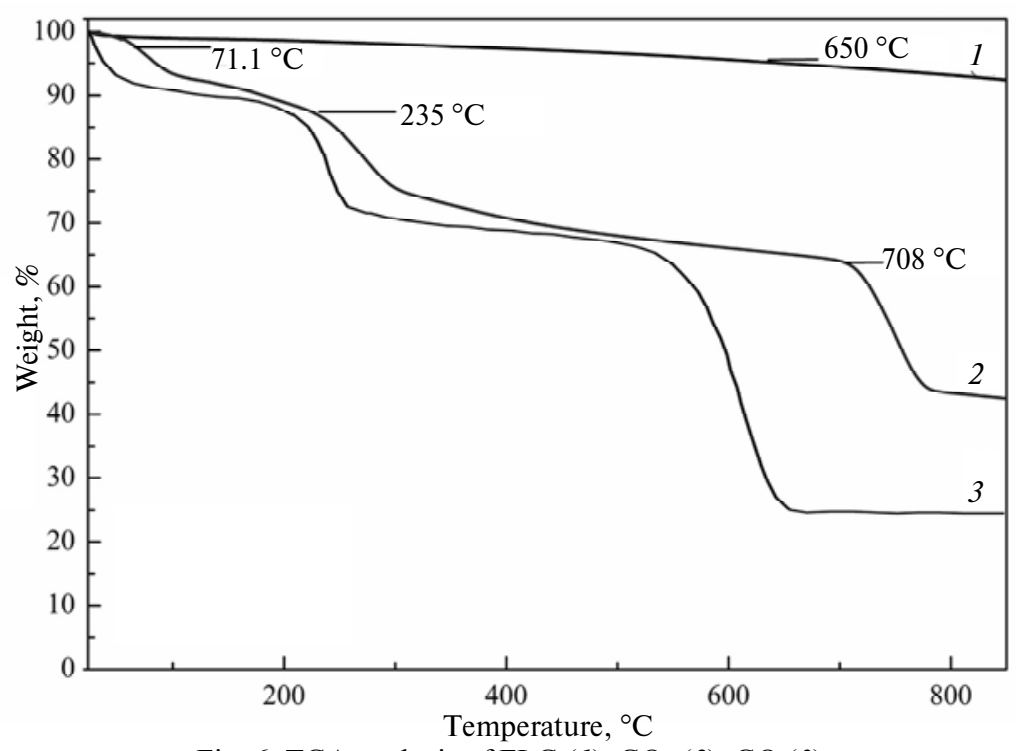

Fig. 6. TGA analysis of FLG (1), $\mathrm{GO}_{n}(2), \mathrm{GO}(3)$. 
$590{ }^{\circ} \mathrm{C}(64 \%)$, which are ascribed to the removal of oxygenated functional groups and carbon combustion to $\mathrm{CO}_{2}$, respectively. The $\mathrm{GO}_{n}$ powder after high concentration base washing exhibit three steps of weight loss starting at $71.1^{\circ} \mathrm{C}(11.3 \%)$ related to the physical adsorbed moisture, the second and the last weight loss at $266{ }^{\circ} \mathrm{C}(32.2 \%)$ and $74{ }^{\circ} \mathrm{C}(57.8 \%)$ which are attributed to the removal of oxygenated functional groups and carbon combustion to $\mathrm{CO}_{2}$, respectively. The results observed that the thermal stability of GO and $\mathrm{GO}_{n}$ are less than that of FLG attributed to the oxidation process. Otherwise, the thermal stability of $\mathrm{GO}_{n}$ is more stable than GO due to the base washing removal of the amorphous carbon.

Table 2. TGA comparison between FLG, GO and $\mathbf{G O}_{n}$

\begin{tabular}{c|c|c|c|c|c|c|c}
\hline \multirow{2}{*}{ Sample } & \multicolumn{7}{c}{$\begin{array}{c}\text { Weight loss, \% } \\
\text { at temperature, }{ }^{\circ} \mathrm{C}\end{array}$} \\
\cline { 2 - 8 } & 46.6 & 58.4 & 71.1 & 200 & 235 & 550 & 708 \\
\hline $\begin{array}{c}\text { Pristine FLG } \\
\mathrm{GO}\end{array}$ & 7.6 & & & & & & \\
$\mathrm{GO}_{\mathrm{n}}$ & & 17 & & 40 & & 64 & \\
\hline
\end{tabular}

\section{CONCLUSION}

FLG powder has been oxidized using modified Hummer's method, the oxidized FLG (GO) has been washed by high base concentration $(10 \mathrm{M} \mathrm{NaOH})$ to enhance the removal efficiency for the carbonaceous fragments. The impact of high concentration base washing on the surface of GO has been studied using: XRD analysis to confirm the degree of crystalline and the interlayer spacing, XRD pattern shows new peaks appeared, lead to the interlayer spacing was increased after oxidation and base washing, attributed to the introduced hydroxyl groups increase the repulsion between graphene sheets due to posting the same negative charge. Raman analysis shows that the amorphous carbon content was diminished after base washing. $\mathrm{GO}_{n}$ is more thermal stable than $\mathrm{GO}$, regarding to the base washing, remove the fragment and enhance the thermal stability. Furthermore, the base washing removed the acid waste by friendly environmental method, low cost, saving the time and the quantity of water needed to eliminate the remained acid.

Методом Хаммера синтезувано оксид графену (ОГ). Цей процес окислення декорує площчини графена різними типами функиіональних груп, жорсткі умови окислення призводять також до появи великої кількості вуглечевовмісних фрагментів, які зменшують ефективність ОГ в багатьох областях його застосування. Синтезований ОГ промивали розчином $10 \mathrm{M} \mathrm{NaOH} \mathrm{для} \mathrm{отримання}(О Г)_{n}$. Якість ОГ досліджено кількома методами: введені в малошаровий графен гідроксильні та карбоксильні групи визначали Фур'є-інфрачервоною спектроскопією, ступінь дефектності та перехід графіту з кристалічної структури в аморфну і навпаки ідентифікували Раманівською спектроскопією, відстань між шарами у малошаровому графені $i(O Г)_{n}$ досліджували з використанням рентгенівської дифракції, а термостабільність вихідних і модифікованих матеріалів термогравіметричним аналізом, морфологію структури характеризували за допомогою скануючої електронної мікроскопії і просвічуючої електронної мікроскопії високої роздільної здатності. Різні дослідження підтвердили, щчо властивості ОГ поліпшувалися під дією нейтралізації, що може прокласти шлях новим розробкам щодо його застосування.

Ключові слова: окислення, оксид графена, малошаровий графен, вуглецевмісні фрагменти, електростатична стабілізація. 
Методом Хаммера синтезировали оксид графена (ОГ). Этот процесс окисления декорирует плоскости графена различными типами функииональных групп, жесткие условия окисления приводят также к появлению большого количества углеродсодержаших фрагментов, которые уменьшают эффективность ОГ во многих областях его применения. Синтезированный ОГ промывали раствором $10 \mathrm{M} \mathrm{NaOH} \mathrm{для} \mathrm{получения}$ ОГ графен гидроксильные и карбоксильные группы определяли Фурье-инфракрасной спектроскопией; степень дефектности и переход графита из кристаллической структуру в аморфную и наоборот идентифицировали Рамановской спектроскопией, расстояние между слоями в малослойном графене и ОГ исследовали с использованием рентгеновской дифракиии, а термостабильность исходных и модифицированных материалов - термогравиметрическим анализом, морфологию структуры характеризовали с помощью сканирующей электронной микроскопии и просвечивающей электронной микроскопии высокого разрешения. Различные исследования подтвердили, что свойства ОГ улучшались под действием нейтрализачии, что может проложить путь новым разработкам по его применению.

Ключевые слова: окисление, оксид графена, малослойный графен, углеродсодержащие фрагменты, электростатическая стабилизация.

1. Dreyer D. R., Park S., Bielawski C. W., Ruoff R. S. The chemistry of graphene oxide // Chem. Soc. Rev. - 2010. - 39. - P. 228-240.

2. Su X., Wang G., Li W. et al. A simple method for preparing graphene nano-sheets at low temperature // Adv. Powder. Technol. - 2013. - 24. - P. 317-323.

3. Slonczewski J. C., Weiss P. R. Band structure of graphite// Phys. Rev. - 1958. - 109. P. 272-279.

4. Novoselov K. S., Geim A. K., Morozov S. V. et al. Electric field effect in atomically thin carbon films // Science. - 2004. - 306. - P. 666-669.

5. Singh V., Joung D., Zhai L. et al. Graphene based materials: Past, present and future // Prog. Mater. Sci. - 2011. - 56. - P. 1178-1271.

6. Kim J., Cote L. J., Kim F. et al. Graphene oxide sheets at interfaces // J. Am. Chem. Soc. 2010. - 132. - P. 8180-8186.

7. Wang G., Wang B., Park J. et al. Synthesis of enhanced hydrophilic and hydrophobic graphene oxide nanosheets by a solvothermal method // Carbon. - 2009. - 47. - P. 68-72.

8. Brodie B. C. On the atomic weight of graphite // Philos. Trans. R. Soc. London. - 1859. -149. - P. 249-59.

9. Staudenmaier L. Method for the preparation of graphitic acid // Ber. Dtsch. Chem. Ges. 1898. - 31. - P. 1481-1487.

10. Hummers W. S., Offeman R. E. Preparation of graphitic oxide // J. Am Chem. Soc. - 1958. 80. - P. 1339-1349.

11. Compton O. C., Nguyen $S-B$. T. Graphene oxide, highly reduced graphene oxide, and graphene: versatile building blocks for carbon-based materials // Small. - 2010. - 6, N 6. P. 711-723.

12. Johnson J. A., Benmore C. J., Stankovich S., Ruoff R. S. A neutron diffraction study of nanocrystalline graphite oxide // Carbon. - 2009. - 47. - P. 2239-2243.

13. Cai W. W., Piner R. D., Stademann F. J., et al. Synthesis and solid-state NMR structural characterization of ${ }^{13} \mathrm{C}$-labeled graphite oxide // Science. - 2008. - 321. - P. 1815-1817.

14. Gao W., Alemany L. B., Ci L., Ajayan P. M. New insights into the structure and reduction of graphite oxide // Nat. Chem. - 2009. - 1. - P. 403-408.

15. He H. Y., Klinowski J., Forster M., Lerf A. A new structural model for graphite oxide // Chem. Phys. Lett. - 1998. - 287. - P. 53-56.

16. Lerf A., He H., Forster M., Klinowski J. Structure of graphite oxide revisited // J. Phys. Chem. B. - 1998. - 102. - P. 4477-4482.

17. Krishnamoorthy K., Veerapandian M., Yun K., Kim S. J. The chemical and structural analysis of graphene oxide with different degrees of oxidation // Carbon. - 2013. - 53. - P. 38-49.

18. Li Z., Zhang W., Luo Y. et al. How graphene is cut upon oxidation // J. Am. Chem. Soc. 2009. - 131. - P. 6320-6321.

19. Shao L., Tobias G., Salzmann C. G. et al. Removal of amorphous carbon for the efficient sidewall functionalisation of single-walled carbon nanotubes // Chem. Comm. - 2007. - 47. P. 5090-5092. 
20. Wang Z., Shirley M. D., Meikle S. T. et al. The surface acidity of acid oxidised multi-walled carbon nanotubes and the influence of in-situ generated fulvic acids on their stability in aqueous dispersions // Carbon. - 2009. - 47. - P. 73-79.

21. Huang $Y$. F., Lin C. W. Facile synthesis and morphology control of graphene oxide/polyaniline nanocomposites via in-situ polymerization process // Polymer. - 2012. - 53. P. 2574-2582.

22. Xin Y., Liu J., Zhou Y. et al. Preparation and characterization of Pt supported on graphene with enhanced electrocatalytic activity in fuel cell // J. Power. Sources. - 2011. - 196. P. 1012-1018.

23. Gunasekaran V., Krishnamoorthy K., Mohan R., Kim S-J. An investigation of the electrical transport properties of graphene-oxide thin films // Mater. Chem. Phys. - 2012. - 132. P. 29-33.

24. Krishnamoorthy K., Navaneethaiyer U., Mohan R. et al. Graphene oxide nanostructures modified multifunctional cotton fabrics // Appl. Nanosci. - 2012. - 2. - P. 119-126.

25. Wang G., Yang J., Park J. et al. Facile synthesis and characterization of graphene nanosheets // J. Phys. Chem. - 2008. - 112. - P. 8192-8195.

26. Lee D. W., Santos L. D. L., Seo J. W. et al. The structure of graphite oxide: Investigation of its surface chemical groups // J. Phys. Chem. B. - 2010. - 114. - P. 5723-5728.

27. Venugopal G., Jung M-H., Suemitsu M., Kim S-J. Fabrication of nanoscale three-dimensional graphite stacked junctions by focused-ion-beam and observation of anomalous transport characteristics // Carbon. - 2011. - 49. - P. 2766- 2772.

28. Vasu K. S., Chakraborty B., Sampath S., Sood A. K. Probing top-gated field effect transistor of reduced graphene oxide monolayer made by dielectrophoresis // Solid State Comm. - 2010. - 150. - P. 1295-1298.

29. Pimenta M. A., Dresselhaus G., Dresselhaus M. S. et al. Studying disorder in graphite-based systems by Raman spectroscopy // Phys. Chem. Phys. - 2007. - 9. - P. 1276-1291.

30. Ferrari A. C. Raman spectroscopy of graphene and graphite: Disorder, electron-phonon coupling, doping and nonadiabatic effects // Solid State Comm. - 2007. - 143. - P. 47-57.

31. Ferrari A. C., Robertson J. Interpretation of Raman spectra of disordered and amorphous carbon // Phys. Rev. B. - 2000. - 61. - P. 14095-14107.

Department of Petroleum Applications,

Received 31.12.14

Egyptian Petroleum Research Institute

Department of Applied Chemistry,

Faculty of Science, Al-Azher University, Egypt 